\title{
Influence of epidermal growth factor and transforming growth factor- $\alpha$ on in vitro maturation of cumulus cell-enclosed bovine oocytes in a defined medium
}

\author{
K. Kobayashi, S. Yamashita and H. Hoshi* \\ Research Institute for the Functional Peptides, Yamagata 990, Japan
}

\begin{abstract}
This study was carried out to determine the effects of growth factors (epidermal growth factor, transforming growth factors- $\alpha$ and $-\beta 1$, basic fibroblast growth factor, insulin), gonadotrophins (LH, FSH), and fetal bovine serum added to TCM199 medium on cumulus expansion and fertilization during in vitro maturation, and on subsequent embryonic development of bovine cumulus cell-enclosed oocytes. Epidermal growth factor, transforming growth factor- $\alpha, \mathrm{LH}$ and FSH enhanced cumulus expansion and oocyte fertilizability. No significant effect was achieved with transforming growth factor- $\beta I$ nor with basic fibroblast growth factor. No additive stimulation on cumulus expansion and oocyte fertilizability was observed when epidermal growth factor was combined with LH or FSH. The addition of either epidermal growth factor or transforming growth factor- $\alpha$ to the maturation medium increased the number of fertilized ova that developed to the blastocyst stage. These results demonstrate the potential use of epidermal growth factor and transforming growth factor- $\alpha$ in obtaining high quality mature bovine oocytes for in vitro fertilization.
\end{abstract}

\section{Introduction}

It is generally accepted that gonadotrophins play a major role in stimulating the resumption of meiosis in mammalian oocytes and in the expansion of the cumulus oophorus in vivo (Lindner et al., 1974; Eppig, 1980; Tsafriri et al., 1982; Eppig and Downs, 1984). However, it is possible that other hormonal factors influence meiotic maturation of mammalian oocytes during the preovulatory period. There have been many studies on the intraovarian regulatory role of growth factors in recent years and there is increasing evidence from these studies that growth factors play an important role in the in vitro maturation of rodent oocytes. Dekel and Sherizly (1985) demonstrated that epidermal growth factor (EGF) induced maturation of rat oocytes in the presence of follicle cells. Similarly, EGF has been shown to induce germinal vesicle breakdown specifically in cumulus cell-enclosed mouse oocytes maintained in meiotic arrest (Downs et al., 1988; Downs, 1989). Transforming growth factor- $\alpha$ (TGF- $\alpha$ ), structurally and functionally related to EGF (Marquardt et al., 1983), also stimulates the meiotic maturation of cumulus cell-enclosed mouse oocytes (Brucker et al., 1991). Feng et al. (1988) found that TGF- $\beta$ stimulates the maturation of follicle-enclosed oocytes and cumulus-oocyte complexes in rats. However, there have been only a few studies on the physiological role of growth factors in bovine oocyte maturation when the cumulus cell-enclosed oocytes are cultured in chemically defined medium.

Several reports indicate that cumulus cells are closely involved in the acquisition of full developmental competence

\footnotetext{
*Correspondence.
}

Received 13 May 1993. during oocyte maturation (Leibfried and First, 1979; Staigmiller and Moor, 1984; Crister et al., 1986). Bovine oocytes failed to mature or had a low maturation rate when oocytes were cultured in the absence of cumulus cells (Leibfried and First, 1979; Fukui and Sakuma, 1980). Cumulus cells that tightly adhered to oocytes become dispersed (that is, undergo cumulus expansion) in response to the endogenous surge of gonadotrophins (Dekel and Phillips, 1979; Eppig, 1980; Leibfried and First, 1982). The expansion of cumulus-oocyte complexes is possibly related to the fertilization rate and to the developmental potential of mammalian oocytes (Schroeder and Eppig, 1984; Vanderhyden and Armstrong, 1989; Chen et al., 1993). Factors inducing cumulus expansion may therefore be of great importance in achieving complete oocyte maturation, which is required for fertilization and subsequent normal embryonic development.

The present study was designed to clarify the positive effect of certain growth factors on the cumulus expansion of cumulus cell-enclosed bovine oocytes in a defined medium. The effect of growth factors on complete oocyte maturation and on the potential for embryonic development following in vitro fertilization was also investigated.

\section{Materials and Methods}

\section{Materials}

Recombinant human EGF was purchased from Wakunaga Pharmaceutical Co., Osaka; recombinant human transforming growth factor- $\alpha$ (TGF- $\alpha$ ) from Earth Pharmaceutical Co., Ltd, Ako, Hyogo; transforming growth factor- $\beta 1$ (TGF- $\beta 1$ ), purified 

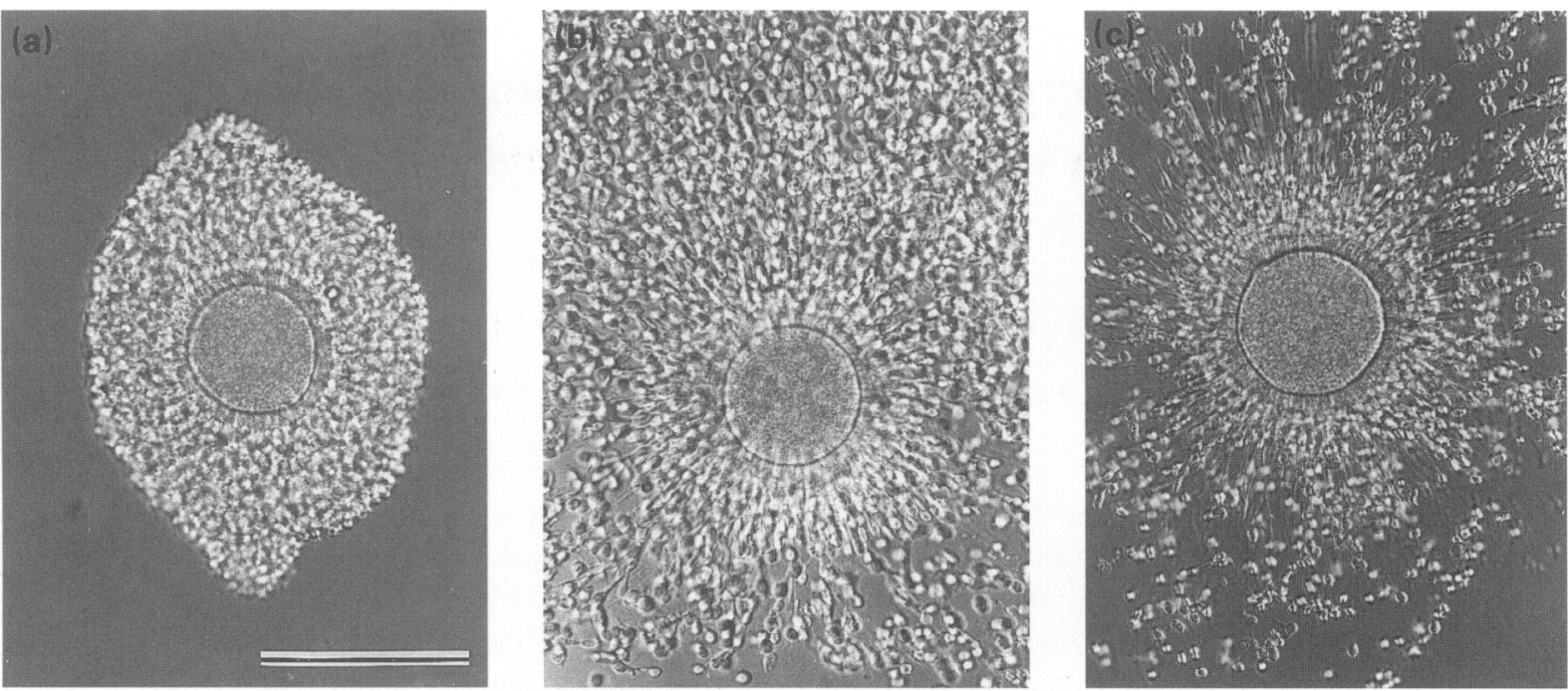

Fig. 1. Bovine cumulus-oocyte complexes exhibiting three degrees of cumulus expansion. (a) Degree 0: no morphological change was observed compared with freshly recovered cumulus-oocyte complexes; (b) degree I: cumulus oophorus slightly expanded but cell to cell binding was still relatively tight; clustered cells were still observed; (c) degree 2: cumulus oophorus was extensively expanded and cumulus cells were homogeneously spread. Differential interference contrast, Nomarski optics. Scale bar represents $200 \mu \mathrm{m}$.

from platelets, and basic fibroblast growth factor (bFGF) from bovine brains from R\&D Systems, Inc., Minneapolis, MN; bovine LH (iodination grade) and FSH (iodination grade) from UCB-Bioproducts SA, Belgium. TCM199 was from Nissui Pharmaceutical Co., Tokyo. Fetal bovine serum (FBS) was from Flow Laboratories, North Ryde. Bovine insulin, fatty acid-free BSA and heparin sodium salt, from porcine intestinal mucosa, were from Sigma Chemical Co., St Louis, MO. Mineral oil was from Squibb and Sons, Inc., Princeton, NJ and type I collagen was from Koken Co., Tokyo. Sixty millimetre tissue culture dishes were from Nunc, Roskilde.

\section{Oocyte recovery and in vitro maturation (IVM)}

Cumulus-oocyte complexes were recovered as described by Kobayashi et al. (1992). Briefly, ovaries from Holstein or Japanese Black cows and heifers were collected at a local abattoir. They were minced with surgical blades in TCM199 supplemented with $25 \mathrm{mmol}_{\text {Hepes }} \mathrm{l}^{-1}, 15 \mu \mathrm{g}$ heparin $\mathrm{ml}^{-1}$, $1.25 \mathrm{mmol}$ sodium pyruvate $\mathrm{l}^{-1}$ and $10 \mu \mathrm{g}$ gentamycin $\mathrm{ml}^{-1}$ (IBL, Fujioka) to release the cumulus-oocyte complexes from small antral follicles. Only oocytes with an unexpected cumulus and homogeneous cytoplasmic granulation were selected. They were placed in $350 \mu \mathrm{l}$ droplets of the maturation media in $60 \mathrm{~mm}$ tissue culture dishes and covered with mineral oil. Each droplet contained approximately 30 cumulus-oocyte complexes. The cumulus-oocyte complexes were then incubated for $24 \mathrm{~h}$ at $38.5^{\circ} \mathrm{C}$ in a humidified atmosphere of $5 \% \mathrm{CO}_{2}: 95 \%$ air

\section{Sperm preparation and in vitro fertilization (IVF)}

Sperm preparation and in vitro fertilization were performed as described by Kobayashi et al. (1992). Briefly, commercially distributed, frozen semen from a single Japanese Black bull preserved in $0.5 \mathrm{ml}$ straws was used. A $0.5 \mathrm{ml}$ straw containing approximately $2 \times 10^{7}$ spermatozoa was rapidly thawed at $34^{\circ} \mathrm{C}$ and spermatozoa were washed twice with $\mathrm{BO}$ medium (Brackett and Oliphant, 1975) containing $5 \mathrm{mmol}$ caffeine $\mathrm{I}^{-1}$ and $15 \mu \mathrm{g}$ heparin $\mathrm{ml}^{-1}$ by centrifugation at $700 \mathrm{~g}$ for $7 \mathrm{~min}$. The resulting spermatozoa pellet was resuspended in $1 \mathrm{ml}$ of the same medium. The concentration of spermatozoa was determined by a haemocytometer and adjusted to $10^{7}$ spermatozoa $\mathrm{ml}^{-1}$ by further dilution. A $50 \mu \mathrm{l}$ aliquot of the spermatozoa suspension was added to $50 \mu \mathrm{l}$ droplets of the $\mathrm{BO}$ medium containing $5 \mathrm{mmol}$ caffeine $\mathrm{l}^{-1}$ and $10 \mathrm{mg} \mathrm{BSA} \mathrm{ml}^{-1}$ placed under mineral oil. After in vitro maturation, the cumulus-oocyte complexes were washed three times with the same medium, transferred to the droplets of spermatozoa suspension and incubated for $6 \mathrm{~h}$ at $38.5^{\circ} \mathrm{C}$ in a humidified atmosphere of $5 \% \mathrm{CO}_{2}: 95 \%$ air.

\section{Embryo culture}

After in vitro fertilization, the cumulus-oocyte complexes were washed three times with TCM199 supplemented with $5 \mu \mathrm{g}$ insulin $\mathrm{ml}^{-1}$, and were transferred to $350 \mu \mathrm{l}$ droplets of the same medium placed under mineral oil. Tissue culture dishes used for embryo cultures were precoated with $100 \mu \mathrm{g}$ Type I collagen $\mathrm{ml}^{-1}$ to enhance the attachment of cumulus cells to culture dishes. Fertilized ova were cocultured with cumulus cells at $38.5^{\circ} \mathrm{C}$ in a humidified atmosphere of $5 \%$ $\mathrm{CO}_{2}: 95 \%$ air.

\section{Evaluation of cumulus expansion}

The proportions of oocytes exhibiting cumulus expansion were determined at the endpoint of in vitro maturation. The degree of cumulus expansion was assessed by the morphology of the cumulus oophorus as follows: degree 0: no expansion 
Table 1. Effects of growth factors and gonadotrophins on cumulus expansion and cleavage of bovine oocytes during in vitro maturation

\begin{tabular}{|c|c|c|c|c|c|}
\hline \multirow[b]{2}{*}{ Treatment } & \multirow{2}{*}{$\begin{array}{c}\text { Number of } \\
\text { cumulus-oocyte } \\
\text { complexes examined }\end{array}$} & \multicolumn{3}{|c|}{ Number $(\%)$ of cumulus-oocyte complexes expanded } & \multirow{2}{*}{$\begin{array}{c}\text { Number (\%) of } \\
\text { fertilized } \\
\text { ova cleaved }\end{array}$} \\
\hline & & Degree 0 & Degree 1 & Degree 2 & \\
\hline None & 127 & $114(89.8 \pm 2.7)$ & $13(10.2 \pm 2.7)$ & 0 & $62(48.8 \pm 7.0)$ \\
\hline EGF & 118 & $0^{\mathrm{a}}$ & $10 \quad(8.5 \pm 5.2)$ & $108(91.5 \pm 5.2)^{\mathrm{a}}$ & $83(70.3 \pm 4.5)^{\mathrm{a}}$ \\
\hline TGF- $\alpha$ & 121 & $0^{a}$ & $7 \quad(5.8 \pm 0.0)$ & $114(94.2 \pm 0.0)^{\mathrm{a}}$ & $89(73.6 \pm 6.1)^{\mathrm{a}}$ \\
\hline TGF- $\beta 1$ & 126 & $119(94.4 \pm 3.8)$ & $7 \quad(5.6 \pm 3.8)$ & 0 & $38(30.2 \pm 5.0)^{\mathrm{b}}$ \\
\hline bFGF & 125 & $108(86.4 \pm 4.1)$ & $17(13.6 \pm 4.1)$ & 0 & $50(40.0 \pm 3.6)$ \\
\hline Insulin & 131 & $101(77.1 \pm 5.8)^{b}$ & $30(22.9 \pm 5.8)^{\mathrm{b}}$ & 0 & $71(54.2 \pm 7.0)$ \\
\hline $\mathrm{LH}$ & 119 & $0^{a}$ & $0^{\mathrm{a}}$ & $119(100.0 \pm 0.0)^{\mathrm{a}}$ & $89(74.8 \pm 6.2)^{a}$ \\
\hline FSH & 117 & $0^{a}$ & $0^{\mathrm{a}}$ & $117(100.0 \pm 0.0)^{\mathrm{a}}$ & $99(84.6 \pm 3.4)^{\mathrm{a}}$ \\
\hline LH plus FSH & 119 & $0^{2}$ & $1(0.8 \pm 1.0)^{\mathrm{b}}$ & $118(99.2 \pm 1.0)^{\mathrm{a}}$ & $80(67.2 \pm 3.3)$ \\
\hline LH plus EGF & 119 & $0^{\mathrm{a}}$ & $0^{a}$ & $119(100.0 \pm 0.0)^{\mathrm{a}}$ & $87(73.1 \pm 10.9)^{\mathrm{a}}$ \\
\hline FSH plus EGF & 116 & $0^{\mathrm{a}}$ & $0^{\mathrm{a}}$ & $116(100.0 \pm 0.0)^{\mathrm{a}}$ & $79(68.1 \pm 9.0)^{\mathrm{b}}$ \\
\hline LH plus FSH plus EGF & 119 & $0^{\mathrm{a}}$ & $0^{\mathrm{a}}$ & $119(100.0 \pm 0.0)^{\mathrm{a}}$ & $88(73.9 \pm 5.6)^{\mathrm{a}}$ \\
\hline FBS & 119 & $2(1.7 \pm 2.9)^{\mathrm{a}}$ & $74(62.2 \pm 7.6)^{\mathrm{a}}$ & $43(36.1 \pm 7.1)^{\mathrm{a}}$ & $78(65.5 \pm 5.6)^{\mathrm{b}}$ \\
\hline
\end{tabular}

EGF: epidermal growth factor; TGF- $\alpha$ : transforming growth factor- $\alpha$; TGF- $\beta 1$ : transforming growth factor- $\beta 1$; bFGF: basic fibroblast growth factor; FBS: fetal bovine serum. Percentages are expressed as means \pm SEM of four replicates. ${ }^{a, b}$ Percentages with a superscript differ from the percentage of the control in each column at ${ }^{a} P<0.001$ and at ${ }^{b} P<0.01$. Data were analysed by $\chi^{2}$ test. Degree of expansion: 0 : no expansion; 1 : cumulus cells nonhomogeneously spread and cells still clustered; 2: cumulus cells homogeneously spread and cells no longer clustered.

was seen; degree $I$ : cumulus cells were nonhomogeneously spread and clustered cells were still observed; degree 2: cumulus cells were homogeneously spread and clustered cells were no longer present. Typical morphology of in vitro matured cumulus-oocyte complexes in these three categories are shown (Fig. 1).

\section{Experiment 1}

The effects of growth factors, gonadotrophins and fetal bovine serum (FBS) added to the maturation medium on cumulus expansion and cleavage were examined. Selected cumulus-oocyte complexes were matured with TCM199 containing EGF (10 $\left.\mathrm{ng} \mathrm{ml}^{-1}\right)$, TGF $\alpha\left(10 \mathrm{ng} \mathrm{ml}^{-1}\right)$, TGF- $\beta 1$ (10 $\mathrm{ng} \mathrm{ml}^{-1}$ ), bFGF (10 $\mathrm{ng} \mathrm{ml}^{-1}$ ), insulin $\left(5 \mu \mathrm{g} \mathrm{ml}^{-1}\right.$ ), LH $\left(5 \mu \mathrm{g} \mathrm{ml}^{-1}\right)$, FSH $\left(500 \mathrm{ng} \mathrm{ml}^{-1}\right)$, combinations of LH, FSH, and EGF (LH plus FSH, LH plus EGF, FSH plus EGF, and LH plus FSH plus EGF, at the same concentrations as indicated above), or FBS (10\%). TCM199 alone served as control medium. After incubation for $24 \mathrm{~h}$, the cumulus-oocyte complexes were observed to determine the degree of cumulus expansion and the ability of oocytes to be fertilized. Fortyeight hours after in vitro fertilization, ova were denuded from the surrounding cumulus cells by pipetting, and observed for the occurrence of cleavage.

\section{Experiment 2}

Dose-dependent stimulation by EGF and TGF- $\alpha$ on cumulus expansion and fertilization was examined. EGF and TGF- $\alpha$ were added to the maturation medium at concentrations of $0,0.01,0.1,1,10$ and $100 \mathrm{ng} \mathrm{ml}^{-1}$. The degree of cumulus expansion and cleavage rates were determined as described in Expt 1.

\section{Experiment 3}

The influence of EGF, TGF- $\alpha$, LH, FSH, and combinations of LH, FSH and EGF during in vitro maturation were tested on cleavage and subsequent embryonic development. The cumulus-oocyte complexes were matured with TCM199 alone or with TCM199 containing EGF, TGF- $\alpha$, LH plus FSH, LH plus FSH plus EGF, or FBS and fertilized. Fertilized cumulusoocyte complexes were then transferred to the development medium (TCM199 supplemented with $5 \mu \mathrm{g}$ insulin $\mathrm{ml}^{-1}$ ) as described above and cocultured with cumulus cells for 9 days without change of medium. Embryos were denuded mechanically, by pipetting, $48 \mathrm{~h}$ after IVF. The concentrations of growth factors, gonadotrophins and serum used in Expt 3 were the same as in Expt 1. The developmental capacity of the fertilized ova was calculated from the proportion of fertilized ova that developed to the blastocyst stage within 9 days after IVF.

\section{Statistical analysis}

The proportion of cumulus-oocyte complexes expanded to the different degrees, the proportion of fertilized ova that cleaved, and the proportion of fertilized ova that developed to the blastocyst stage were compared by $\chi^{2}$ test. In Expts 1,2 and 3 , a comparison was made between each treatment and the corresponding control.

\section{Results}

\section{Experiment 1}

The effects on cumulus expansion and cleavage of adding the different growth factors, gonadotrophins and serum to the 

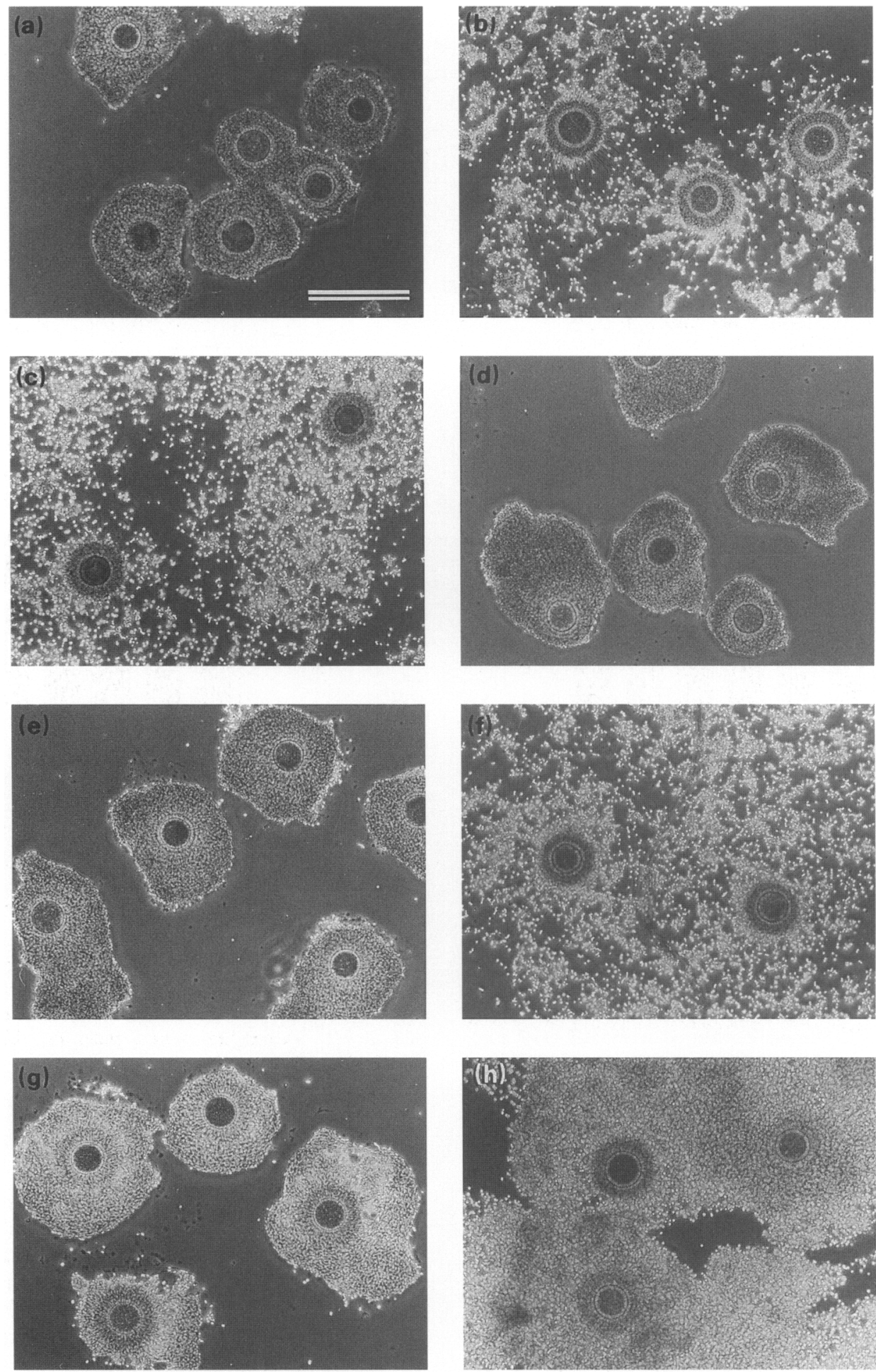

Fig. 2. Bovine cumulus-oocyte complexes cultured for $24 \mathrm{~h}$ in different maturation media. (a) TCM199 alone; (b) epidermal growth factor (10 $\left.\mathrm{ng} \mathrm{ml}{ }^{-1}\right)$; (c) transforming growth factor- $\left(10 \mathrm{ng} \mathrm{ml}^{-1}\right.$ ); (d) transforming growth factor- $\beta 1$ (10 ng $\mathrm{ml}^{-1}$ ); (e) basic fibroblast growth factor (10 $\mathrm{ng} \mathrm{ml}^{-1}$ ); (f) LH $\left(5 \mu \mathrm{g} \mathrm{ml}^{-1}\right.$ ) plus FSH $\left(0.5 \mu \mathrm{g} \mathrm{ml}^{-1}\right)$; (g) insulin $\left(5 \mu \mathrm{g} \mathrm{ml}{ }^{-1}\right)$; (h) fetal bovine serum (10\%). Phase contrast. Scale bar represents $400 \mu \mathrm{m}$.

maturation medium are summarized (Table 1). The data are from four replicates. Microscope observations of cumulusoocyte complexes cultured for $24 \mathrm{~h}$ are shown (Fig. 2).
When cumulus-oocyte complexes were incubated in TCM 199 alone, only $10.2 \%$ (13 of 127) of the cumulus-oocyte complexes showed any expansion (degree 1) and no fully 

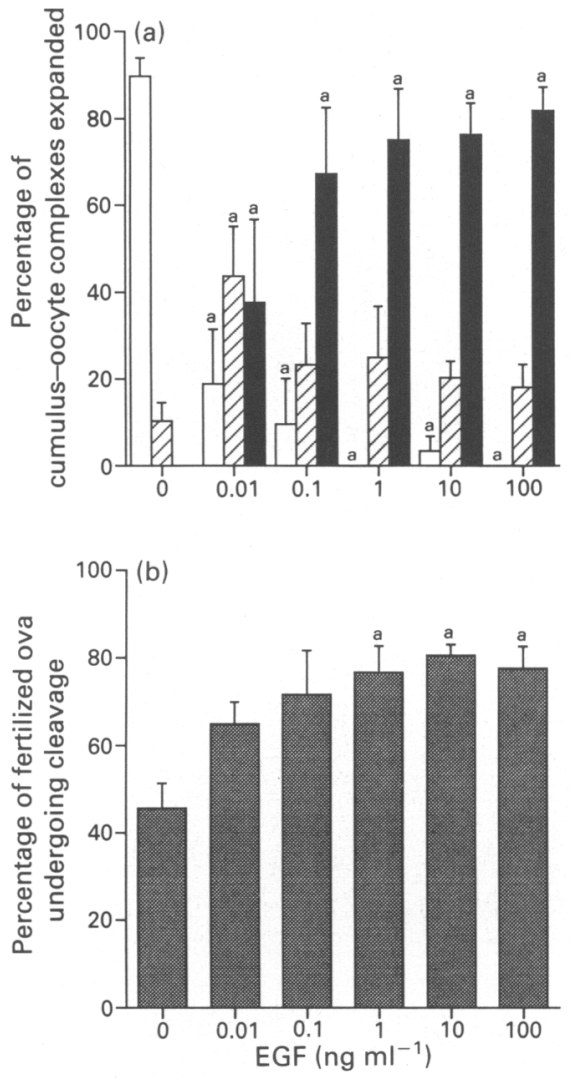

Fig. 3. Effect of epidermal growth factor (EGF) on cumulus expansion and cleavage of bovine oocytes during in vitro maturation. (a) Percentage of cumulus-oocyte complexes expanded to degree $0(\square)$, degree $1(\mathbb{A})$, and degree 2 ( $\boldsymbol{\square})$. Degree 0 : no expansion; degree 1 : cumulus cells nonhomogeneously spread and cells still clustered; degree 2: cumulus cells homogeneously spread and cells no longer clustered. (b) Percentages of fertilized ova undergoing cleavage. Values are expressed as means \pm SEM from four replicates. Total numbers of oocytes examined at the EGF concentrations of $0,0.01$, $0.1,1,10$, and $100 \mathrm{ng} \mathrm{ml}^{-1}$ were 116, 117, 116, 116, 118 and 116 .

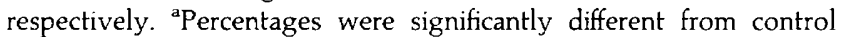
$\left(P<0.001 ; \chi^{2}\right.$ test $)$.

expanded cumulus-oocyte complexes (degree 2) were observed. Most (89.8\%; 114 of 127) of the cumulus-oocyte complexes remained unexpanded with the cumulus cells still tightly bound to oocytes (Table 1, Fig. 2a).

EGF and TGF- $\alpha$ greatly increased $(P<0.001)$ the proportion of cumulus-oocyte complexes with cumulus expansion. Cumulus-oocyte complexes incubated in the media containing EGF or TGF- $\alpha$ all exhibited cumulus expansion, and more than $90 \%$ reached degree $2(91.5 \% ; 108$ of 118 and $94.2 \% ; 114$ of 121, respectively). No significant difference on cumulus expansion was observed between EGF and TGF- $\alpha$. Enhancement of cumulus expansion by these two growth factors was comparable to the effects of LH and FSH which also stimulated cumulus expansion intensively with all the cumulus-oocyte complexes reaching degree 2 (Fig. $2 \mathrm{f}$ ). Cumulus expansion was also induced in the presence of FBS $(98.3 \%$; 117 of 119); although a high percentage $(62.2 \% ; 74$ of 119$)$ then remained at degree 1 . The binding of cumulus cells surrounding the oocytes appeared looser; however, the cells did not spread as exten-
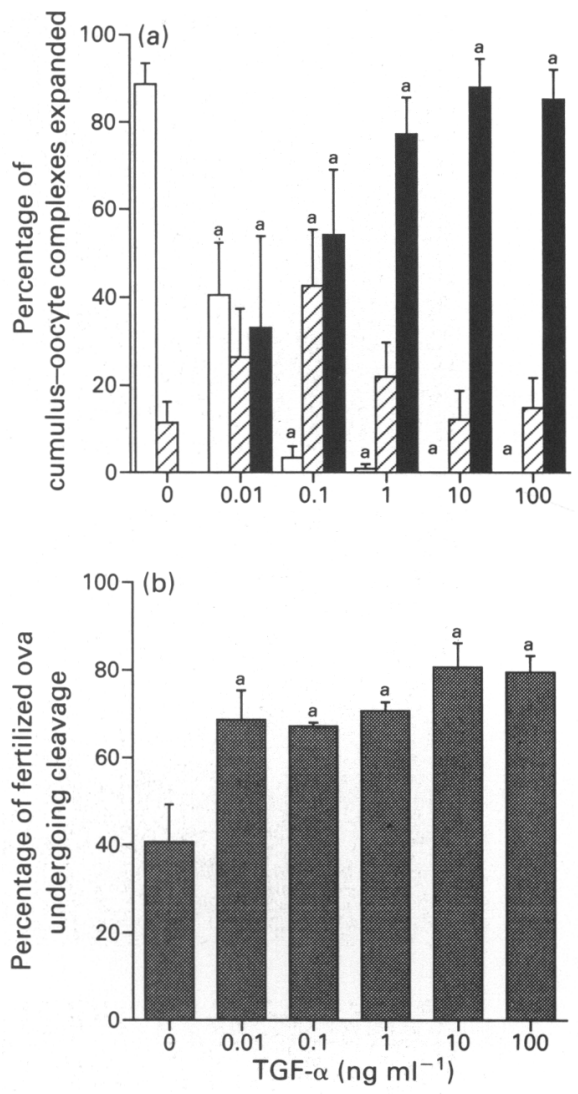

Fig. 4. Effect of transforming growth factor- $\alpha$ (TGF- $\alpha$ ) on cumulus expansion and cleavage of bovine oocytes during in vitro maturation. (a) Percentages of cumulus-oocyte complexes expanded to degree 0 ( $\square$ ), degree 1 ( $(\Delta)$, and degree 2 ( $\square$ ). Degree 0 : no expansion; degree 1: cumulus cells nonhomogeneously spread and cells still clustered; degree 2: cumulus cells homogeneously spread and cells no longer clustered. (b) Percentages of fertilized ova undergoing cleavage. Values are expressed as means \pm SEM from four replicates. Total numbers of oocytes examined at the TGF- $\alpha$ concentrations of $0,0.01$, $0.1,1,10$, and $100 \mathrm{ng} \mathrm{ml}^{-1}$ were $123,121,122,123,124$ and 122 , respectively. ${ }^{2}$ Percentages were significantly different from control $\left(P<0.001 ; \chi^{2}\right.$ test $)$.

sively compared with complexes stimulated by EGF, TGF- $\alpha$, $\mathrm{LH}$ or FSH.

A significant $(P<0.01)$ increase in fertilization rate was also observed with EGF $(70.3 \%$; 83 of 118$)$ or TGF- $\alpha(73.6 \%$; 89 of 121) compared with control medium $(48.8 \%$; 62 of 127). Similarly, higher proportions of cumulus-oocyte complexes cleaved in the presence of $\mathrm{LH}(74.8 \% ; 89$ of 119$), \mathrm{FSH}$ $(84.6 \% ; 99$ of 117$)$ or FBS $\{65.5 \% ; 78$ of 119$)$. However, there were no significant differences $(P>0.05)$ in cleavage rate among media containing EGF, TGF- $\alpha, \mathrm{LH}, \mathrm{FSH}$ or FBS. No additive effect was observed on the number of ova that cleaved during IVM when EGF was combined with LH or FSH.

TGF- $\beta 1$ and bFGF had no significant effect on cumulus expansion and slightly reduced cleavage rates $(30.2 \%$; 38 of 126 and $40.0 \%$; 50 of 125 , respectively).

The addition of insulin resulted in a higher proportion (22.9\%; 30 of 131) of cumulus-oocyte complexes expanding to 
Table 2. Effect of EGF and TGF- $\alpha$ on in vitro development of bovine oocytes during in vitro maturation

Number (\%) of ova

\begin{tabular}{lcrr} 
Treatment & Number of ova & Undergoing cleavage & Developing to blastocyst \\
\cline { 3 - 4 } None & 194 & $98(50.5 \pm 4.6)^{\mathrm{a}}$ & $19(9.8 \pm 1.9)^{\mathrm{c}}$ \\
EGF & 196 & $152(77.6 \pm 5.2)^{\mathrm{b}}$ & $35(17.9 \pm 3.7)^{\mathrm{d}}$ \\
TGF- $\alpha$ & 198 & $156(78.8 \pm 4.5)^{\mathrm{b}}$ & $42(21.2 \pm 4.6)^{\mathrm{d}}$ \\
LH plus FSH & 195 & $136(69.7 \pm 2.7)^{\mathrm{b}}$ & $31(15.9 \pm 3.5)^{\mathrm{cdd}}$ \\
LH plus FSH plus EGF & 198 & $155(78.3 \pm 3.8)^{\mathrm{b}}$ & $38(19.2 \pm 3.2)^{\mathrm{d}}$ \\
FBS & 198 & $156(78.8 \pm 1.7)^{\mathrm{b}}$ & $38(19.2 \pm 0.7)^{\mathrm{d}}$
\end{tabular}

Percentages are expressed as means \pm SEM of seven replicates.

Percentages with different superscripts are significantly different ${ }^{a, b} P<0.001 ;{ }^{c, d} P<0.05$.

EGF: epidermal growth factor; TGF- $\alpha$ : transforming growth factor- $\alpha$; FBS: fetal bovine serum.

Data were analysed by $\chi^{2}$ test.

degree 1 ( $P<0.01$ ). Insulin slightly increased the fertilization rate, but the difference from controls was not statistically significant $(P>0.05)$.

\section{Experiment 2}

Dose-dependent stimulation by EGF or TGF- $\alpha$ of cumulus expansion and cleavage rate was determined. Data are from four replicates. The proportion of cumulus-oocyte complexes exhibiting cumulus expansion (degree 1 plus degree 2) was increased significantly $(P<0.001)$ by the addition of EGF at a concentration as low as $0.01 \mathrm{ng} \mathrm{ml}^{-1}$ with all cumulus-oocyte complexes exhibiting cumulus expansion at $1 \mathrm{ng} \mathrm{ml} \mathrm{ml}^{-1}$ (Fig. 3a). The maximum effect of EGF was observed at $100 \mathrm{ng} \mathrm{ml}^{-1}$; however, differences were not significant among the doses used ( 1 to $100 \mathrm{ng} \mathrm{ml}^{-1} ; P>0.05$ ). EGF also increased the fertilization rate in a dose-dependent manner (Fig. 3b). Maximum stimulation was observed at $10 \mathrm{ng} \mathrm{ml}^{-I}$, but there were no significant differences $(P>0.05)$ among the doses of I-100 $\mathrm{ng} \mathrm{ml}^{-1}$

TGF- $\alpha$ enhanced cumulus expansion and rate of fertilization in a dose-dependent manner (Fig. 4a, b). The proportion of cumulus-oocyte complexes exhibiting cumulus expansion (degree 1 plus degree 2 ) was significantly increased $(P<0.001)$ at $0.01 \mathrm{ng} \mathrm{ml}$ and nearly all complexes had expanded at doses of 0.1 to $100 \mathrm{ng} \mathrm{ml}^{-1}$. The maximum effect on cumulus expansion to degree 2 was observed at $10 \mathrm{ng} \mathrm{ml}^{-1}$. The highest rate of cleavage was obtained at $10 \mathrm{ng} \mathrm{ml}^{-1}$, but differences were not significant among doses of $0.01-100 \mathrm{ng} \mathrm{ml}^{-1}(P>0.05)$.

\section{Experiment 3}

The effects of growth factors, gonadotrophins or serum added to the maturation medium on cleavage and subsequent embryo development are summarized (Table 2). The data are from seven replicates.

The cleavage rate of cumulus-oocyte complexes incubated in TCM199 alone was 50.5\% (98 of 194) and the proportion of fertilized ova developing to blastocyst was $9.8 \%$ (19 of 194).

Consistent with the results of Expts 1 and 2, cleavage rates were significantly increased $(P<0.001)$ by the addition of EGF $(77.6 \%$; 152 of 196$)$ or TGF- $\alpha(78.8 \% ; 156$ of 198$)$. The proportion of fertilized ova that developed to blastocysts was also significantly increased $(P<0.05)$ by the addition of EGF (17.9\%; 35 of 196$)$ or TGF- $\alpha(21.2 \% ; 42$ of 198). The effects of EGF on fertilization rate and blastocyst formation were unchanged by further supplementation with gonadotrophins $(P>0.05)$.

Other treatments (LH plus FSH or FBS) also had a positive effect on cleavage rate and subsequent embryo development. However, cleavage rate and blastocyst formation with these treatments were not significantly different from those in EGF-containing medium.

\section{Discussion}

The present study demonstrates that exposure of cumulusenclosed bovine oocytes during in vitro maturation to EGF and TGF- $\alpha$ stimulated cumulus expansion and oocyte fertilizability when cultured in defined medium. Consistent with previous findings (Ball et al., 1983; Brackett et al., 1989; Younis et al., 1989; Zuelke and Brackett, 1990), LH or FSH, alone and in combination, also stimulated cumulus expansion and oocyte fertilizability. However, combinations of EGF and gonadotrophins had no additive or synergistic effect on oocyte fertilizability and subsequent development to the blastocyst stage.

These results suggest that the stimulatory mechanisms of EGF and gonadotrophins are mediated by the same physiological process. Downs et al. (1988) reported that FSH and EGF stimulated cAMP production and germinal vesicle breakdown in mouse cumulus-oocyte complexes. As dibutyryl cAMP also stimulates germinal vesicle breakdown, they proposed that FSH and EGF act via a cAMP-dependent process. Moreover, cumulus expansion of mouse cumulus-oocyte 
complexes occurs after the increase in cAMP (Buccione $e t$ al., 1990). It is therefore possible that in bovine cumulus-oocyte complexes EGF and gonadotrophins act via a cAMP. dependent process.

Ova, matured in medium with added EGF or TGF- $\alpha$, developed to the blastocyst stage at as high a rate as ova matured in the presence of FBS, when these ova were fertilized and cocultured with cumulus or granulosa cells in insulincontaining medium. In our previous study (Hoshi et al., 1991), the addition of insulin during embryo culture potentiated the rate of blastocyst formation with cumulus or granulosa cell monolayer cultures in a chemically defined medium after the cumulus-oocyte complexes were matured in medium containing FBS. The result that EGF alone improved fertilizability and developmental capacity is in agreement with the results of Coskun et al. (1991) who assessed the development to the 4- to 8-cell stage. Harper and Brackett (1993) reported that during IVM EGF, in a defined medium, improved the number of bovine ova developing to blastocysts after IVF, although the requirement for gonadotrophins ( $\mathrm{FSH}$ or $\mathrm{LH}$ ) in the action of EGF in their study differed from the present study.

The stimulatory action of EGF on oocyte maturation was observed in mice (Downs et al., 1988), mice and humans (Das et al., 1991) and rats (Dekel and Sherizly, 1985). Downs (1989) examined a number of growth factors (TGF- $\beta$, platelet-derived growth factor, nerve growth factor, insulin-like growth factor-I and II, insulin, and FGF) and demonstrated that the stimulatory action was specific to EGF. Similar results were obtained in this study. No positive effects on cumulus expansion nor on bovine oocyte fertilizability were observed with insulin, bFGF or TGF- $\beta 1$. Basic FGF and TGF- $\beta$ I slightly inhibited cleavage rate. TGF- $\alpha$, which has similar biological functions to EGF and binds to the same receptors, also stimulates meiotic maturation of cumulus-enclosed mouse oocytes (Brucker et al., 1991). TGF- $\alpha$ also mimics the action of LH on oocyte maturation by inducing meiotic resumption in follicle-enclosed rat oocytes (Tsafriri et al., 1989).

It is of interest that although the number of cleaved ova that matured in TCM199 medium alone was significantly lower than in the presence of EGF (77.6\%) and TGF- $\alpha$ (78.8\%), 50.5\% of control cumulus-oocyte complexes underwent fertilization and cleavage and a small number $(9.8 \%)$ developed to the blastocyst stage. This result is in agreement with the findings of Zuelke and Brackett (1990) who found that almost $50 \%$ of bovine oocytes matured in TCM199 medium alone could be fertilized and cleaved to two-cell and four-cell stages by $48 \mathrm{~h}$ after IVF. In a study of different nutrient media used for maturation of bovine oocytes, Rose and Bavister (1992) reported that TCM199 is one of the best nutrient media for normal oocyte maturation. The choice of TCM199 as basal medium for IVM may therefore facilitate fertilization. With regard to in vitro development, Takagi et al. (1991) found that the use of Type $I$ collagen-precoated dishes during embryo culture after IVF resulted in improved cumulus cell proliferation and embryo development in a serum-free medium. Since IVF and embryonic development were successful in TCM199 medium alone during IVM, it remains unclear whether the cumulus expansion induced by EGF-like molecules and gonadotrophins is directly related to the increased fertilizability and subsequent embryonic development.
In conclusion, EGF-like molecules enhance bovine oocyte maturation in vitro in a chemically defined medium as reflected in improved fertilization and subsequent embryonic development in vitro. The IVM culture system with defined medium is useful for investigating specific molecular mechanisms by which EGF-like molecules stimulate oocyte maturation and improve the overall efficiency of embryo production.

The authors are very grateful to Y. Oike for her technical assistance and to the Yamagata Nairiku Meat Inspection Office and Yamagata-ken Shokuniku Kosha for supplying bovine ovaries. This work was supported by the Research Fund from the Biooriented Technology Research Advancement Institution (BRAIN) of Japan.

\section{References}

Ball GD, Leibfried ML, Lenz RW, Ax RL, Bavister BD and First NL (1983) Factors affecting successful in vitro fertilization of bovine follicular oocytes Biology of Reproduction 28 717-725

Brackett BG and Oliphant G (1975) Capacitation of rabbit spermatozoa in vitro Biology of Reproduction 12 260-274

Brackett BG, Younis AI and Fayrer-Hosken RA (1989) Enhanced viability after in vitro fertilization of bovine oocytes matured in vivo with high concentrations of luteinizing hormone Fertility and Sterility 52 319-324

Brucker C, Alexander NJ, Hodgen GD and Sandow BA (1991) Transforming growth factor-alpha augments meiotic maturation of cumulus celI-enclosed mouse oocytes Molecular Reproduction and Development 28 94-98

Buccione R, Vanderhyden BC, Caron PJ and Eppig JJ (1990) FSH-induced expansion of the mouse cumulus oophorus in vitro is dependent upon a specific factor(s) secreted by the oocyte Developmental Biology $\mathbf{1 3 8}$ $16-2.5$

Chen L, Russell PT and Larsen WJ (1993) Functional significance of cumulus expansion in the mouse: roles for the preovulatory synthesis of hyaluronic acid within the cumulus mass Molecular Reproduction and Development 34 $87-93$

Coskun S, Sanbuissho A, Lin YC and Rikihisa Y (1991) Fertilizability and subsequent development ability of bovine oocytes matured in medium containing epidermal growth factor (EGF) Theriogenology 36 485-494

Crister ES, Leibfried-Rutledge ML, Eyestone WH and Northey DL (1986) Acquisition of developmental competence during maturation in vitro Theriogenology 25150 (Abstract)

Das K, Tagatz GE, Stout LE, Phipps WR, Hensleigh HC and Leung BS (1991) Direct positive effect of epidermal growth factor on the cytoplasmic maturation of mouse and human oocytes Fertility and Sterility $\mathbf{5 5}$ $1000-1004$

Dekel N and Phillips DM (1979) Maturation of the rat cumulus oophorus: a scanning microscopic study Biology of Reproduction 21 9-18

Dekel N and Sherizly I (1985) Epidermal growth factor induces maturation of rat follicle-enclosed oocytes Endocrinology 116 406-409

Downs SM (1989) Specificity of epidermal growth factor action on maturation of the murine oocyte and cumulus oophorus in vitro Biology of Reproduction $41371-379$

Downs SM, Daniel AJ and Eppig JJ (1988) Induction of maturation in cumulus cell enclosed mouse oocytes by follicle-stimulating hormone and epidermal growth factor: evidence for a positive stimulus of somatic cell origin Journal of Experimental Zoology 245 86-96

Eppig JJ (1980) Regulation of cumulus oophorus expansion by gonadotrophins in vivo and in vitro Biology of Reproduction 23 545-552

Eppig JJ and Downs SM (1984) Chemical signals that regulate mammalian oocyte maturation Biology of Reproduction 30 1-11

Feng P, Catt KJ and Knecht M (1988) Transforming growth factor- $\beta$ stimulates meiotic maturation of the rat oocyte Endocrinology 122 181-186

Fukui $Y$ and Sakuma $Y$ (1980) Maturation of bovine oocytes cultured in vitro: relation to ovarian activity, follicular size and the presence or absence of cumulus cells Biology of Reproduction 22 669-673

Harper KM and Brackett BG (1993) Bovine blastocyst development after in vitro maturation in a defined medium with epidermal growth factor and low concentrations of gonadotrophins Biology of Reproduction 48 409-416 
Hoshi H, Takagi Y, Kobayashi K, Onodera M and Oikawa T (1991) Growth and function of bovine granulosa cells cultured in a serum-free medium. In Animal Cell Culture and Production of Biologicals pp 213-219 Eds R Sasaki and K Ikura. Kluwer Academic Publishers, Dordrecht

Kobayashi K, Takagi Y, Satoh T, Hoshi H and Oikawa T (1992) Development of early bovine embryos to the blastocyst stage in serum-free conditioned medium from bovine granulosa cells In Vitro Cellular and Developmental Biology 28A 255-259

Leibfried ML and First NL (1979) Characterization of bovine follicular oocytes and their ability to mature in vitro Journal of Animal Science 48 76-86

Leibfried ML and First NL (1982) Preovulatory changes in cumulus-oocyte complex of the hamster Anatomical Record 202 339-348

Lindner HR, Tsafriri A, Lieberman ME, Zor U, Koch Y, Bauminger S and Barnea A (1974) Gonadotrophin action on cultured Graafian follicles: induction of maturation division of the mammalian oocyte and differentiation of the luteal cell Recent Progress in Hormone Research 30 79-138

Marquardt H, Hunkapiller MW, Hood LE, Twardzik DR, De Larco JE, Stephenson JR and Todaro GJ (1983) Transforming growth factors produced by retrovirus-rodent fibroblasts and human melanoma cells: amino acid sequence homology with epidermal growth factor Proceedings of National Academy of Sciences USA $\mathbf{8 0} 4684-4688$

Rose TA and Bavister BD (1992) Effect of oocyte maturation medium on in vitro development of in vitro fertilized bovine embryos Molecular Reproduction and Development 31 72-77
Schroeder AC and Eppig JJ (1984) The developmental capacity of mouse oocytes that matured in vitro is normal Developmental Biology 102 493-498

Staigmiller RN and Moor RM (1984) Effect of follicle cells on the maturation and developmental competence of ovine oocytes matured outside the follicle Gamete Research 9 221-229

Takagi Y, Mori K, Tomizawa M, Takahashi T, Sugawara S and Masaki J (1991) Development of bovine oocytes matured, fertilized and cultured in a serum-free, chemically defined medium Theriogenology 35 1197-1207

Tsafriri A, Dekel N and Bar-ami S (1982) The role of oocyte maturation inhibitor in follicular regulation of oocyte maturation Journal of Reproduction and Fertility 64 541-551

Tsafriri A, Vale W and Hsueh AJW (1989) Effects of transforming growth factors and inhibin-related proteins on rat preovulatory Graafian follicles in vitro Endocrinology 125 1857-1862

Vanderhyden BC and Armstrong DT (1989) Role of cumulus cells and serum on the in vitro maturation, fertilization, and subsequent development of rat oocytes Biology of Reproduction $\mathbf{4 0} 720-728$

Younis AI, Brackett BG and Fayrer-Hosken RA (1989) Influence of serum and hormones on bovine oocyte maturation and fertilization in vitro Gamete Research 23 189-201

Zuelke KA and Brackett BG (1990) Luteinizing hormone-enhanced in vitro maturation of bovine oocytes with and without protein supplementation Biology of Reproduction 43 784-787 